\title{
Article \\ Performance Optimization of Solar-Assisted Heat Pump System for Water Heating Applications
}

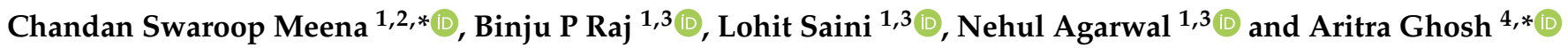 \\ 1 CSIR—Central Building Research Institute, Roorkee 247667, India; binjupraj94@gmail.com (B.P.R.); \\ lohitsaini@gmail.com (L.S.); nehulagarwal4641@gmail.com (N.A.) \\ 2 Academy of Scientific and Innovative Research (AcSIR), Ghaziabad 201002, India \\ 3 Thapar Institute of Engineering and Technology, Patiala 147001, India \\ 4 College of Engineering, Mathematics and Physical Sciences, Renewable Energy, University of Exeter, \\ Penryn, Cornwall TR10 9FE, UK \\ * Correspondence: chandan@cbri.res.in (C.S.M.); a.ghosh@exeter.ac.uk (A.G.)
}

check for updates

Citation: Meena, C.S.; Raj, B.P.; Saini, L.; Agarwal, N.; Ghosh, A. Performance Optimization of Solar-Assisted Heat Pump System for Water Heating Applications. Energies 2021, 14, 3534. https://doi.org/ $10.3390 /$ en14123534

\section{Academic Editors: Carlos Pozo}

Fernández, Ángel Galán Martín and Jae-Weon Jeong

Received: 23 April 2021

Accepted: 10 June 2021

Published: 14 June 2021

Publisher's Note: MDPI stays neutral with regard to jurisdictional claims in published maps and institutional affiliations.

Copyright: (C) 2021 by the authors. Licensee MDPI, Basel, Switzerland. This article is an open access article distributed under the terms and conditions of the Creative Commons Attribution (CC BY) license (https:/ / creativecommons.org/licenses/by/ $4.0 /)$.

\begin{abstract}
The use of solar energy in water heating applications, such as in solar-assisted heat pump systems, has great benefits, such as reductions in heat transfer losses, control over incident solar heat, and generation of environmentally benign water heat. In the present study, we performed parametric optimization based on an experimental model of a solar-assisted heat pump system for water heating (SAHPSWH) in the context of colder climatic regions receiving minimal solar radiation. Various parameters were investigated, such as the different glazing arrangements, the distances between fluid-circulating tubes, and the absorber sheet arrangement. The results showed that double glazing was more efficient than single glazing, with average COP values of 3.37 and 2.69, respectively, and with similar heat gain rates. When the evaporator tube was soldered below the absorber plate, the COP was 1.19 times greater than when the tube was soldered above the absorber plate. We also analyzed whether the collector efficiency factor $\mathrm{F}^{\prime}$ has an inverse relationship with the tube distance and a direct relationship with the absorber plate thickness. Through this experimental study, we verified that the SAHPSWH is reliable if designed judiciously. This promising energy-saving system is particularly suitable for areas abundant in solar radiation, such as in India, where the needs for space conditioning and water heating are constant.
\end{abstract}

Keywords: thermal performance; renewable energy; heat pump; solar radiation; flat plate collector

\section{Introduction}

To construct energy-efficient sustainable buildings in compliance with the emerging regulations for global warming and greenhouse gas (GHG) emissions, several changes are required [1,2]. The use of renewable sources of energy to achieve this goal has largely been endorsed [3]. Among the renewable sources, solar energy is the most readily available source of clean energy, with minimal costs and environmental impacts [4]. Applications based on solar thermal energy have gained massive attention from 1970's onwards, following the beginning of the energy crisis [5]. The process of collecting solar arrays in the form of energy and converting them into useful heat for water heating, space conditioning, or agricultural or industrial applications is the basis of solar thermal applications [6]. Solar water heating accounts for a major proportion of all applications in the market; however, various technical flaws, such as uncertainty related to the heat gain efficiency and heat loss, act as barriers to its promotion [7]. The integration of heat pumps for thermal applications can potentially rectify such issues [8]. The solar-assisted heat pump system for water heating (SAHPSWH) has advantages over conventional solar water heaters in terms of performance and initial investment, even under changing conditions and uneven weather. The conventional systems contain water as the working fluid, while hybrid water heating systems use a refrigerant as the working fluid, which transfers heat to the water [9]. 
The SAHPSWH solves the common issues of conventional systems regarding the high investment costs for collector components and the problems that arise due to corrosion. In contrast, the SAHPSWH is able to work under moderate climatic conditions with solar radiation, enhancing the energy efficiency of buildings [10]. A plethora of research studies have experimentally and numerically [11] evaluated the potential of solar thermal hot water collectors and their combination with heat pumps to reduce site energy consumption in heating applications.

Jose et al. analyzed a SAHPSWH experimentally for sub-zero temperature conditions and observed a COP value of 3.01 when heating $300 \mathrm{~L}$ from 14 to $55^{\circ} \mathrm{C}$ at an ambient temperature of $21.9^{\circ} \mathrm{C}$ over $638 \mathrm{~min}$, along with observing a transient increase in the heating process during the first $15 \mathrm{~min}$ before reaching a trans-steady-state [12]. A study based on an economic comparison between a SAHPSWH and a conventional system for tropical and sub-tropical regions showed decreased annual operating costs, with a notable payback time and the need for different configurations based on climatic variations [13].

By modifying solar collectors with corrugated metal roofing and a copper tube, along with a compressor speed of $20 \mathrm{rps}$ and mass flow rate of $0.01 \mathrm{~kg} / \mathrm{s}$, the COP values obtained were between 2.5 and 5.0. The suitable mass for the storage tank was $400 \mathrm{~kg}$ with a payback time of 2.3 years [14]. A combined SAHPSWH with serial and parallel modes was experimentally and numerically validated, with the results suggesting the use of the serial mode in winter and parallel mode in summer, with an annual average COP of 5.7 [15]. A numerical study validated the performance of the SAHPSWH under frosting conditions, showing reliable heating performance with an average COP of 2.75 and delayed frost formation in comparison with a traditional system. This clearly showed that with decreased ambient temperature and increased solar radiation intensity, frost formation can be prohibited [16].

In [17], an experimental setup involving a SAHPSWH was structured for the purpose of both water and space heating, resulting in a COP of 2.1 for water heating and an average COP of 2.5 for space heating under variable climate conditions. Tagliafico et al. [18] showed the SAHPSWH approach to be very efficient, even for uneven weather conditions, proving the approach to be environmentally friendlier than a traditional solar heater integrated into a gas burner. The average savings in energy consumption based on different glazing configurations were also analyzed.

Cutic et al. [19] determined that COP levels are significantly altered by alterations in solar radiation based on convection theory, enabling the absorption of heat due to higher ambient temperatures and lower evaporation temperatures. Bastos et al. [20] studied the SAHPSWH prototype for the purpose of heating residential water via numerical simulations and experimental validation, proving that the power consumed by the compressor varied due to radiation and wind speed. Additionally, a decrease was observed in the COP because of a pressure loss in the evaporator and due to the compressor not being thermally insulated.

Buker and Riffat [21] studied a system in which solar thermal collectors were combined with heat pumps in a single SAHPSWH, which can be used for various purposes. They reviewed various systems from the past and present using visualizations, systematic representations, and component classification. They experienced challenges in classifying the systems based on a variety of parameters, configurations, and performance criteria, which increased the level of complexity. Additionally, they found that there were separate effects of solar heat energy on the collector efficiency and heat pump, concluding that the SAHPSWH has great potential and could be an alternative for various purposes and different climatic zones around the world.

Chaturvedi et al. [22] studied a sustainable SAHPSWH for low-temperature water heating applications, analyzing the energy savings and economic feasibility of the system. The thermal performance of the system was simulated with the help of computer software, which embedded location-based irradiation, collector, heat pump, and other data. The economic feasibility was checked with the help of the life cycle cost (LCC) method. It 
was found that the direct expansion approach of the SAHPSWH when compared with a conventional electric water heater was economical, conserving energy by $60 \%$. This system can fulfill the demands of low-temperature water heating applications.

From the above studies, it can be inferred that the SAHPSWH is a good alternative for various climatic zones around the world in terms of cost-effectiveness and energy conservation. The COP values for the system vary with different structural arrangements or with variations in solar radiation intensity and ambient temperature. The economic analysis conducted for the system both numerically and experimentally validated its proficiency, showing that different meteorological conditions require specific configurations to achieve better performance. Although several studies have been presented in this review, the full range of applications of this technology is still to be shown, since laboratory-based experiments and real-world conditions are different. This study represents one such realworld scenario, involving different optimization strategies. To the best of our knowledge, as highlighted in the literature, there is no evidence of experimental optimization based on permutations and combinations of tube arrangements and different glazing layers for a composite climate. In this study, an experimental effort is made to optimize the design parameters and identify the best design strategies that may help in reducing the complexity while classifying the system.

An experimental study is performed in a composite climate in India at $29.8543^{\circ} \mathrm{N}$, $77.8880^{\circ} \mathrm{E}$, during the winter season, with an average temperature range of $15-20^{\circ} \mathrm{C}$. This is done in order to tune the conditions to the colder climatic zone of India, so that the results of this study can be used by designers for colder climates. With the help of mathematical modeling, the system components are designed. The SAHPSWH is essentially designed for domestic applications, but with further exploration could be used for commercial applications. The experiment is conducted in an ingenious manner by using a multiobjective optimization approach, resulting in different seasonal arrangements with certain permutations and combinations. Minute effects of plate and tube arrangements in accordance with suitable weather are observed. An extensive glazing and tube arrangement study is performed in the present experiments. Firstly, the effects of different configurations of evaporator tubes on the collector performance are evaluated, while simultaneously the effects of glazing on the overall performance of the system are observed, showing that this technology is sustainable for water heating applications.

The remainder of the paper is as follows. Section 2 describes the case study and methodology employed for the experiment. Section 3 provides insights into the experimental setup and instruments used. Section 4 presents the results of the experimental investigation, while the last section provides concluding remarks.

\section{Methodology}

The solar water heater's performance can be enhanced either by reducing the top heat loss or by improving the convective heat transfer coefficients by changing the working fluid and extracting that heat via a heat exchanger. In this study, the primary concern was the enhancement of the thermal performance of the SAHPSWH. The effects of different parameters, such as the configuration of the collector tubes, glazing material, ambient conditions, and solar intensity on the flat plate collector efficiency, were assessed to expand its commercial applications. An experimental setup was constructed as shown in Figure 1, in which necessary parameters and component specifications, such as the absorber plate thickness, the distance between the collector tubes, and tube diameter, were first optimized using mathematical models, along with climatic variations measured by various measurement devices. The experiment was performed in a composite climate in India in a low-cost bamboo house to completely replicate the winter climatic conditions in the country, which was then supported by theoretical analysis. The readings during the experiment were taken at five-minute intervals. 


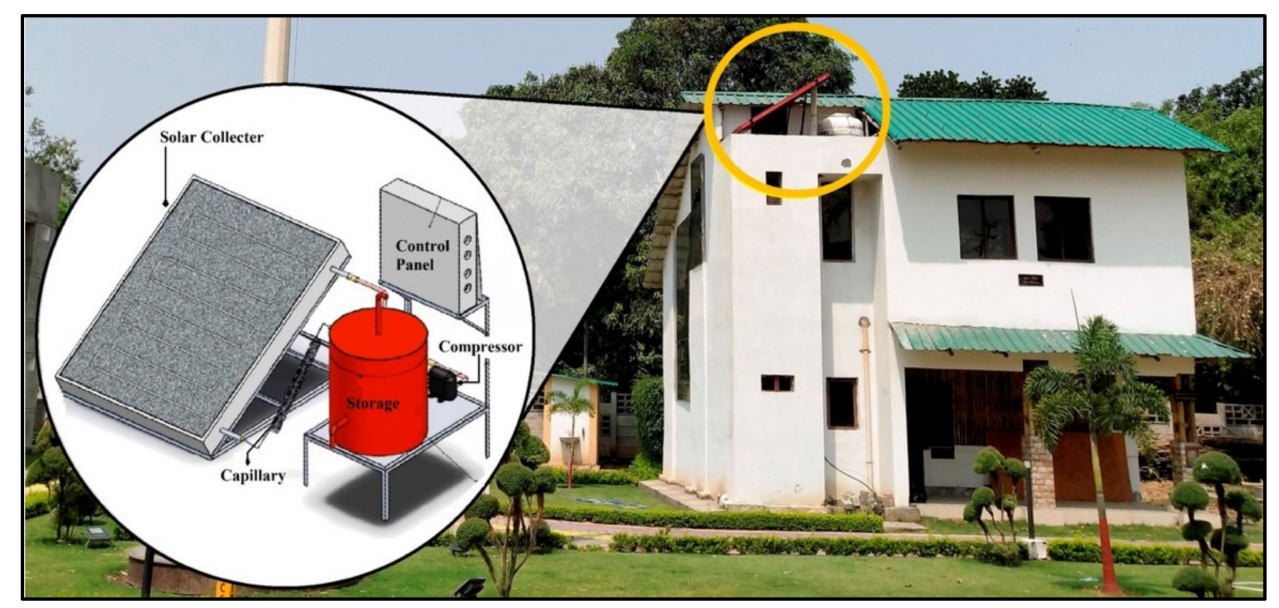

Figure 1. In-field experimental setup (location: $29.8543^{\circ} \mathrm{N}, 77.8880^{\circ} \mathrm{E}$ ).

\subsection{Mathematical Modeling}

For the prediction of the thermal performance, a 1-D mathematical model was built to predict the thermal performance, which was grounded on certain assumptions:

- The system is at a quasi-steady state within the chosen time interval;

- Negligible pressure drops occur in the evaporator, condenser, and piping;

- Both at the exits of the condenser and the evaporator, the refrigerant is considered to be saturated;

- Compression of the refrigerant vapor is assumed to follow a polytropic process;

- Expansion of the refrigerant liquid is considered to be isenthalpic;

- $\quad$ The hot water storage tank is assumed to be non-stratified [23-29].

\subsection{Thermal Performance of the Glazed Flat Plate Collector}

Various operational and design variables influence the performance of solar collectors. The useful heat gain of the collector $\left(Q_{u}\right)$ can be evaluated using three governing parameters: the collector efficiency factor $\mathrm{F}^{\prime}$, the overall heat loss coefficient $\mathrm{U}_{\mathrm{L}}$, and the effective transmittance-absorptance product of the cover system $(\tau \alpha)$. Under steady-state conditions, when tubes are placed above the operating absorber plate, the $Q_{u}$ of a glazed collector can be evaluated as [30]:

$$
\mathrm{Q}_{\mathrm{u}}=\mathrm{F}^{\prime} \mathrm{A}_{\mathrm{c}}\left[(\tau \alpha) \mathrm{I}_{\mathrm{T}}-\mathrm{U}_{\mathrm{L}}\left(\mathrm{T}_{\mathrm{e}}-\mathrm{T}_{\mathrm{a}}\right)\right]
$$

$\mathrm{U}_{\mathrm{L}}$ is primarily due to the convection and radiation heat transfer from the top surface of the collector to the surroundings. $\mathrm{U}_{\mathrm{L}}$ can be evaluated as follows:

$$
\mathrm{U}_{\mathrm{L}}=\mathrm{U}_{\mathrm{b}}+\mathrm{U}_{\mathrm{t}}+\mathrm{U}_{\mathrm{e}}
$$

The bottom heat loss and edge heat loss are both assumed to be negligible. The top loss coefficient can be computed with the help of an empirical equation derived by Klein [31]:

$$
\mathrm{U}_{\mathrm{t}}=\left[\frac{\mathrm{M}}{\left(\frac{\mathrm{C}}{\mathrm{T}_{\mathrm{P}}}\right)\left\{\frac{\mathrm{T}_{\mathrm{P}}-\mathrm{T}_{\mathrm{a}}}{\mathrm{M}+\mathrm{f}}\right\}^{\mathrm{e}}}+\frac{1}{\mathrm{~h}_{\mathrm{w}}}\right]^{-1}+\left[\frac{\sigma\left(\mathrm{T}_{\mathrm{P}}^{2}+\mathrm{T}_{\mathrm{a}}^{2}\right)\left(\mathrm{T}_{\mathrm{P}}+\mathrm{T}_{\mathrm{a}}\right)}{\left(\varepsilon_{\mathrm{p}}+0.059 \mathrm{Mh}_{\mathrm{w}}\right)^{-1}+\left\{\frac{\left(2 \mathrm{M}+\mathrm{f}-1+0.133 \varepsilon_{\mathrm{p}}\right)}{\varepsilon_{\mathrm{g}}}\right\}-\mathrm{M}}\right]
$$

where:

$$
\begin{gathered}
\mathrm{f}=\left(1+0.089 \mathrm{~h}_{\mathrm{w}}-0.116 \mathrm{~h}_{\mathrm{w}} \varepsilon_{\mathrm{p}}\right)(1+0.07866 \mathrm{M}) \\
\mathrm{e}=0.43\left(1-\frac{100}{\mathrm{~T}_{\mathrm{P}}}\right)
\end{gathered}
$$


and:

$$
C=520\left(1-0.000051 \beta^{2}\right) \text { for } 0<\beta<70^{\circ} \text {; use } \beta=70^{\circ} \text { when } 70^{\circ}<\beta<90^{\circ}
$$

For the single-glazed flat plate collector, $\mathrm{M}=1$, while for the double-glazed flat plate collector, $\mathrm{M}=2$.

The convection heat transfer coefficient, $\mathrm{h}_{\mathrm{w}}$, for the outer glass cover is determined regarding the wind velocity $\mathrm{V}$ on the collector surface by the following formulae in cases where the forced flow convection prevails:

$$
\mathrm{h}_{\mathrm{w}}=5.7+3.8 \mathrm{~V}
$$

\section{A. Tubes soldered above the absorber plate}

When tubes are soldered above the absorber plate, the following expression developed by Hottel-Whilliar-Bliss is used to determine $\mathrm{F}^{\prime}$ [32]:

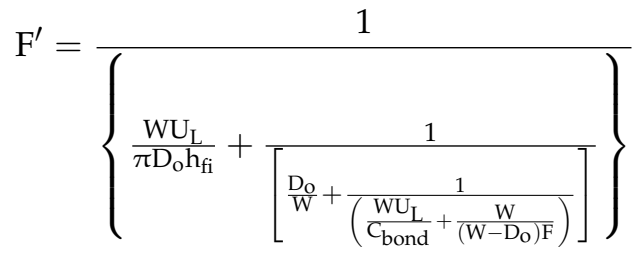

where,

$$
\mathrm{F}=\frac{\tanh \left[\mathrm{m}\left(\mathrm{W}-\mathrm{D}_{\mathrm{o}}\right) / 2\right]}{\left[\mathrm{m}\left(\mathrm{W}-\mathrm{D}_{\mathrm{o}}\right) / 2\right]}
$$

and

$$
\mathrm{m}=\sqrt{\mathrm{U}_{\mathrm{L}} / \mathrm{k}_{\mathrm{p}} \delta_{\mathrm{p}}}
$$

\section{B. Tubes soldered below the absorber plate}

When tubes are soldered below the absorber plate, $\mathrm{F}^{\prime}$ can be evaluated by using the following expression developed by Hottel-Whilliar-Bliss [33,34]

$$
\begin{gathered}
\mathrm{F}^{\prime}=\left[\frac{\frac{1}{\mathrm{U}_{\mathrm{L}}}}{\mathrm{W}\left[\left(\frac{1}{\mathrm{U}_{\mathrm{L}}\left[\mathrm{D}_{\mathrm{o}}+\left(\mathrm{W}-\mathrm{D}_{\mathrm{o}}\right) \mathrm{F}\right]}\right)+\frac{1}{\mathrm{C}_{\mathrm{b}}}+\frac{1}{\pi \mathrm{D}_{\mathrm{i}} \mathrm{h}_{\mathrm{fi}}}\right]}\right] \\
\mathrm{F}=\frac{\tanh \left[\mathrm{m}\left(\mathrm{W}-\mathrm{D}_{\mathrm{o}}\right) / 2\right]}{\left[\mathrm{m}\left(\mathrm{W}-\mathrm{D}_{\mathrm{o}}\right) / 2\right]} \\
\mathrm{m}=\sqrt{\mathrm{U}_{\mathrm{L}} / \mathrm{k}_{\mathrm{p}} \delta_{\mathrm{p}}}
\end{gathered}
$$

The refrigerant mass flow rate can be determined from the volumetric efficiency of the compressor by using the equations derived by Huang and Chyng [35]:

$$
\dot{\mathrm{m}}_{\mathrm{r}}=\frac{\eta_{v} \times \mathrm{V}_{\mathrm{D}}}{v}
$$

where:

$$
\eta_{v}=-0.0163 \times\left(\frac{P_{2}}{P_{1}}\right)+0.6563
$$

The efficiency of the flat plate collector is as follows:

$$
\eta=\frac{\mathrm{Q}_{\mathrm{u}}}{\mathrm{A}_{\mathrm{c}} \mathrm{I}_{\mathrm{T}}}
$$




\section{Coefficient of Performance (COP) of the SAHPWSH System}

The performance of the hybrid model can be determined by its coefficient of performance. The COP of the heat pump can be evaluated as:

$$
\begin{gathered}
\mathrm{COP}=\frac{\text { Themal energy rejected by the condensor }}{\text { Energy input to the compressor }} \\
\mathrm{COP}=\frac{\mathrm{Q}_{\mathrm{c}}}{\mathrm{W}_{\mathrm{comp}}}
\end{gathered}
$$

\section{Experimental Setup and Instrumentation}

The SAHPSWH shown in Figure 2 is a configuration that directly uses the solar collector in place of the evaporator in the cycle to reduce inefficient thermodynamic processes across eliminated components. Based on different studies and the present observations, the SAHPSWH has several advantages, which were attributed to the plate thickness being in the range of 1-5 mm, resulting in a significant increase in the COP by $0.5 \%$ but with no further increases found after $5 \mathrm{~mm}$. Copper and aluminium are regarded as ideal materials for manufacturing solar collectors, as they have good $\mathrm{K}$ values and high ductility. Using R-134a as the refrigerant in the system can result in COP values at least $15 \%$ higher than those obtained using refrigerant mixtures (R-404a, R-407c, and R-410a). The critical design properties of the refrigerant allowing satisfactory system performance are the high thermal conductivity, evaporation enthalpy, and critical temperature. R134a leads to minimum corrosion problems; thus, its life is typically ten times that of the collector carrying water as a fluid. The very low freezing point of the refrigerant can be advantageous in experiments. By eliminating the intermediate exchanger required in the conventional system, this improves the thermal performance of the SAHPSWH. The system uses a solar collector for the evaporator-compressor to increase the system performance, using a condenser as the heat transfer unit and a capillary as the expansion device, with the following specifications for the main components.

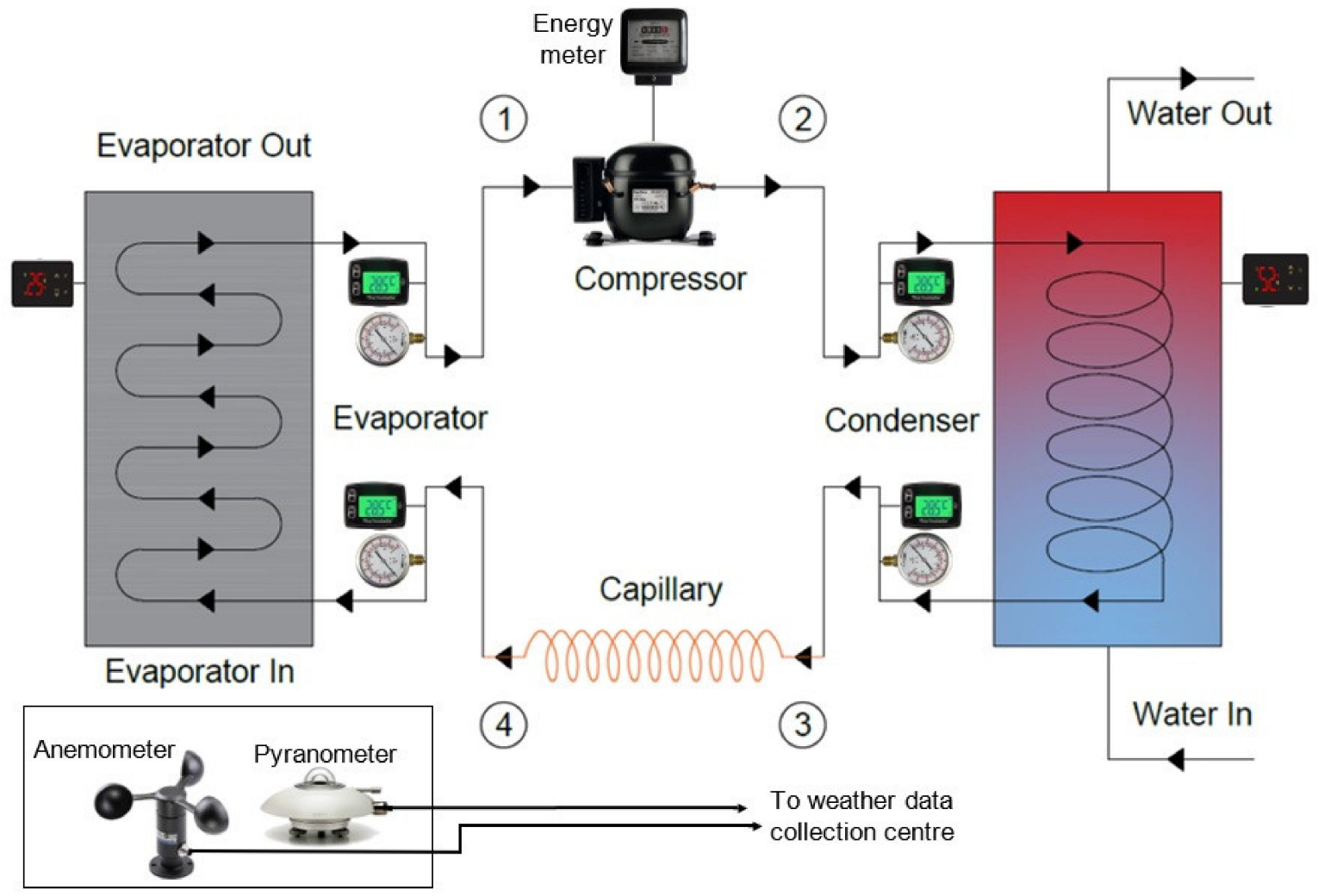

Figure 2. Schematic diagram of the SAHPSWH. 
Collector: In the study, we used a flat plate collector measuring $1.83 \mathrm{~m}(\mathrm{~L}) \times 1.22 \mathrm{~m}$ $(\mathrm{W}) \times 0.1 \mathrm{~m}(\mathrm{~T})$ with transparent glazing as a cover on the top of a 0.3 -mm-thick dark copper plate absorber incorporated in an extruded aluminum collector box. Different types of glazing were utilized to minimalize the heat from the absorber plate top. Fiberglass wool was used as insulation to minimize the heat loss from the bottom and side of the collector, along with an insulation cover for the probable exposure area responsible for the occurrence of heat loss. Solar radiation passes through the transparent glazing on the absorber plate over a $2.1 \mathrm{~m}^{2} \pm 0.1 \mathrm{~m}^{2}$ absorbing area. The heat absorbed is then transferred to the R-134a refrigerant flowing in the tubes, with inner and outer diameters of 7.8 and $8.5 \mathrm{~mm}$, respectively, brazed with an absorber plate. These absorber plates were layered with selective black chrome paint to absorb maximum radiation.

Compressor: A reciprocating hermetically sealed compressor with an input power of $245 \mathrm{~W}$ and a flow rate of $5.79 \mathrm{cc} / \mathrm{rev}$ was incorporated, working on the basic principle of increasing the pressure of the refrigerant by reducing the volume of the fluid. The compressor increases the refrigerant pressure, which significantly contributes towards increases in the refrigerant temperature.

Capillary: An optimized 0.91-mm-diameter copper capillary with a length of $3.048 \mathrm{~m}$ was used in the construction. Two parallel $1.52 \mathrm{~mm}$ capillaries were used with a copper filter. Before entering the evaporator again, it became necessary to normalize the temperature and pressure of the refrigerant. Therefore, after losing latent heat, a reduction in pressure can be achieved via the diffusion action within the capillary, thereby increasing the volume of the refrigerant fluid, leading to a decrease in the pressure amongst the refrigerant.

Condenser: The condenser was used here to transfer heat to the water. The main function of a condenser is to condense a refrigerant from its gaseous state to a liquid state, after which its latent heat is moved to the storage tank. The condenser consisted of copper tubes with an outer diameter $(9.525 \mathrm{~mm})$ and length of $9.75 \mathrm{~m}$ immersed in the storage tank, which was assumed to be non-stratified, i.e., losses can be neglected while determining the coefficient of performance.

Instrumentation/Measuring Devices: The apparatus was in the appropriate arrangement to evaluate the system performance under different conditions. The measuring devices used to collect the necessary data were a 4-channel SZ-7504 temperature scanner, a SZ-7569-P temperature scanner, a pressure gauge, a pyranometer, an anemometer, a sling psychrometer, an energy meter, a voltmeter, and an ammeter, with a differential pressure switch as a safety device. To calculate the COP of the system, temperature readings were taken from 4 points, namely at the inlet of the evaporator-collector, the outlet of the evaporator-collector, the discharge port of the compressor, and the condenser outlet using type 1 and type 2 thermocouples. Table 1 shows the measuring devices with their measurement and uncertainty ranges.

Table 1. Measuring devices with measurement range and uncertainty data.

\begin{tabular}{ccc}
\hline Measuring Instrument & Measurement Range & Uncertainty \\
\hline Type 1 thermocouple & $-50-99{ }^{\circ} \mathrm{C}$ & $\pm 0.1^{\circ} \mathrm{C}$ \\
\hline Type 2 thermocouple & $-100-200{ }^{\circ} \mathrm{C}$ & $\pm 0.1^{\circ} \mathrm{C}$ \\
\hline Pressure gauge (bourdon type) & $600-4000 \mathrm{mbar}$ & $\pm 1 \%$ \\
\hline Pyranometer TBQ-2 & $0-2000 \mathrm{Wm}^{-2}$ & $7-14 \mu \mathrm{V} \cdot \mathrm{W}^{-1} \mathrm{~m}^{2}$ \\
\hline Anemometer & $0.9-0.35 \mathrm{~m} / \mathrm{s}$ & $0.2-0.6 \%$ \\
\hline
\end{tabular}

\section{Results and Discussion}

Experiments with different sheet and tube arrangements in the flat plate collector of the SAHPSWH with single-glazed and double-glazed evaporators were conducted under different conditions. The effects of the tank temperature and evaporation temperature on the COP of the hybrid system, of the heat transfer rate across the condenser, of solar 
radiation on the tank temperature, and of the various parameters of the solar flat plate collector were investigated.

\subsection{Effects of Different Tube Configurations}

The nomenclature for the absorber plate and tube used for the experimental study is shown in Figure 3 , where $D_{i}$ is the internal diameter of the tube, $D_{0}$ is the external diameter of the tube, $\mathrm{b}$ represents the bond width between the serpentine tube and the absorber plate with thickness $\delta$, and $\delta_{t}$ is the thickness of the serpentine tube used.

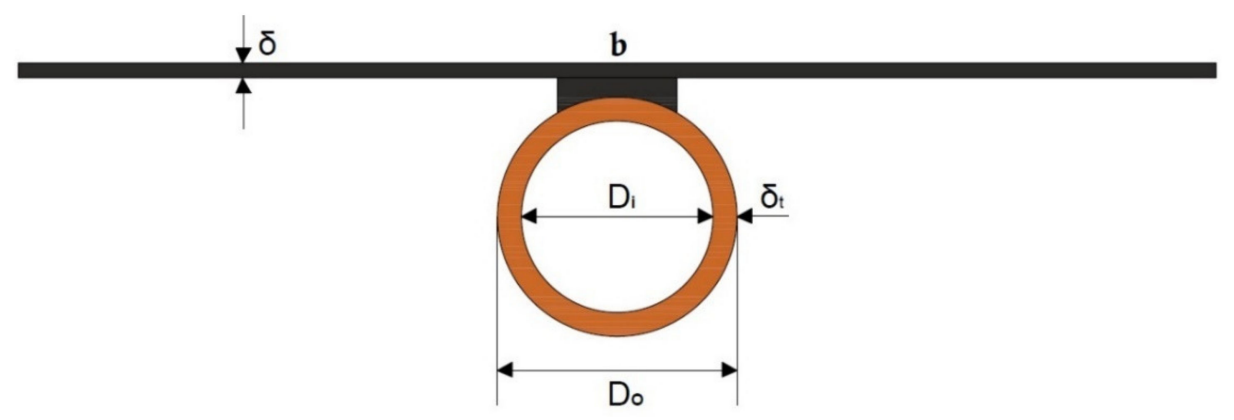

Figure 3. Nomenclature used for absorber plate and tube configuration.

Geometrical and physical data for the tubes obtained from the mathematical modelling for the optimization of the SAHPWHS are represented in Table 2.

Table 2. Geometrical and physical data for evaporator tubes.

\begin{tabular}{cccc}
\hline \multicolumn{2}{c}{ Geometrical Data } & \multicolumn{2}{c}{ Physical Data } \\
\hline $\mathbf{W}(\mathbf{m})$ & 0.1 & $\mathbf{I}_{\mathrm{T}}\left(\mathbf{W m} \mathbf{m}^{-\mathbf{2}}\right)$ & $284-705$ \\
\hline $\mathbf{D}_{\mathbf{i}}(\mathbf{m})$ & 0.0078 & $\mathbf{U}_{\mathbf{L}}\left(\mathbf{W m} \mathbf{m}^{-\mathbf{2}} \mathbf{K}^{-\mathbf{1}}\right)$ & $5.26-6.08$ \\
\hline $\mathbf{D}_{\mathbf{o}}(\mathbf{m})$ & 0.0085 & $\mathbf{h}_{\mathbf{f i}}\left(\mathbf{W m} \mathbf{m}^{-\mathbf{2}} \mathbf{K}^{-\mathbf{1}}\right)$ & 1000 \\
\hline$\delta(\mathbf{m})$ & 0.0003 & $\mathbf{k}\left(\mathbf{W m} \mathbf{K}^{-\mathbf{1}}\right)$ & 387 \\
\hline $\mathbf{A}_{\mathbf{c}}\left(\mathbf{m}^{\mathbf{2}}\right)$ & 2.23 & $\tau \alpha$ & 0.8 \\
\hline
\end{tabular}

The following two cases were considered to evaluate the effects of different tube configurations on the solar plate collector. Case 1: In this case, the evaporator tubes were soldered above the absorber plate, with the cross-section area of the serpentine tubes shown in Figure 4a. Case 2: In this case, the evaporator tubes were soldered beneath the absorber plate SAHPSWH, with the cross-section area of the serpentine tubes shown in Figure 4b.

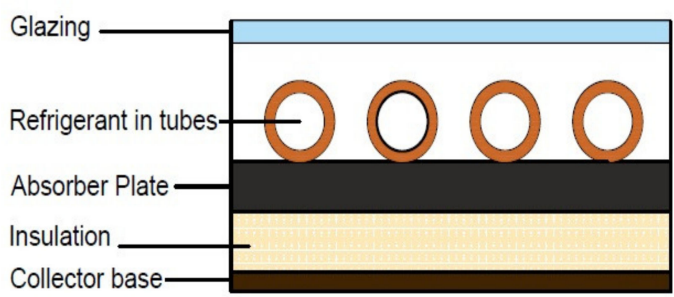

(a)

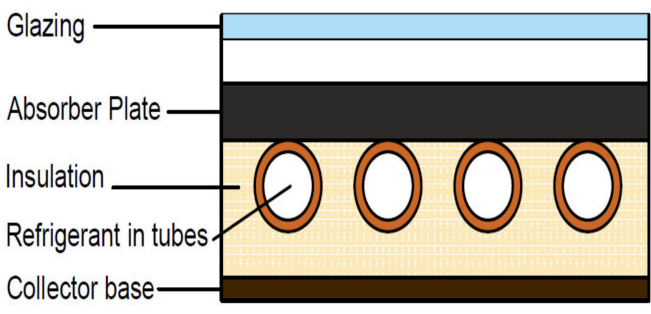

(b)

Figure 4. Cross-sections of the serpentine tubes: (a) above the absorber plate; (b) below the absorber plate.

The experiment was performed in a cold climate after establishing steady-state conditions with varying solar intensities on different days and with variations in ambient 
temperatures. The data recordings for solar intensity were carried out at $30 \mathrm{~min}$ intervals for the two cases, which were almost the same as observed in Figure 5.

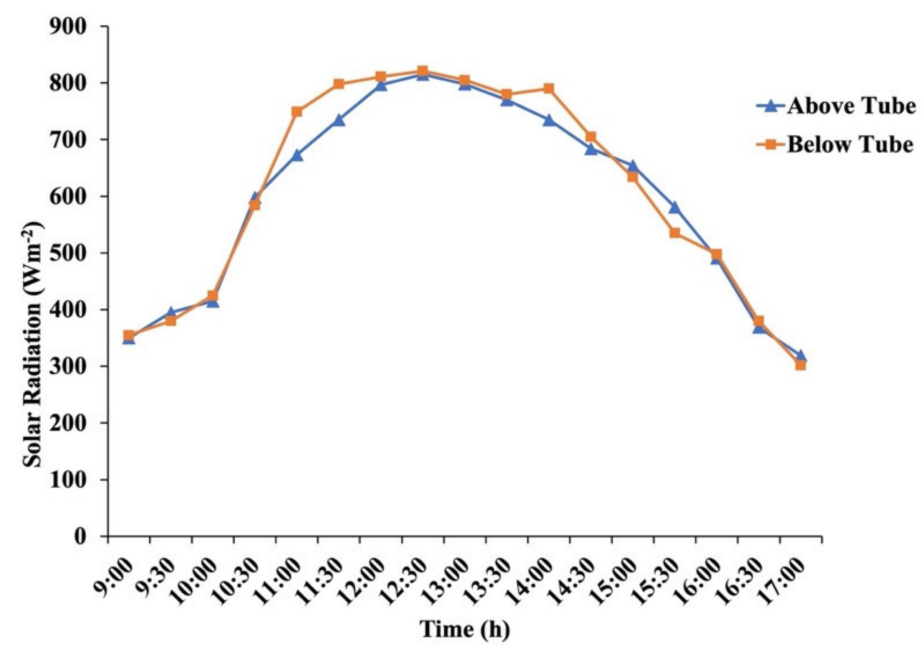

Figure 5. Solar intensity variations with time.

The thickness of the absorber plate and pitch $\mathrm{W}$ (center-to-center distance of tubes) were mathematically computed for economical optimization of the experiment, as a low value of $W$ will result in an increased length and a higher $\delta$ value will increase the material cost. Additionally, the $\mathrm{F}^{\prime}$ value was observed to be strongly influenced by $\mathrm{W}$ and $\delta$ in Figure $6 \mathrm{a}, \mathrm{b}$, as $\mathrm{F}^{\prime}$ increased with an increase in the thickness of the absorber plate and correspondingly decreased with an increase in the $\mathrm{W}$ value; therefore, the optimal pitch and thickness for absorber plate for the experiment were 0.1 and $0.003 \mathrm{~m}$, respectively.

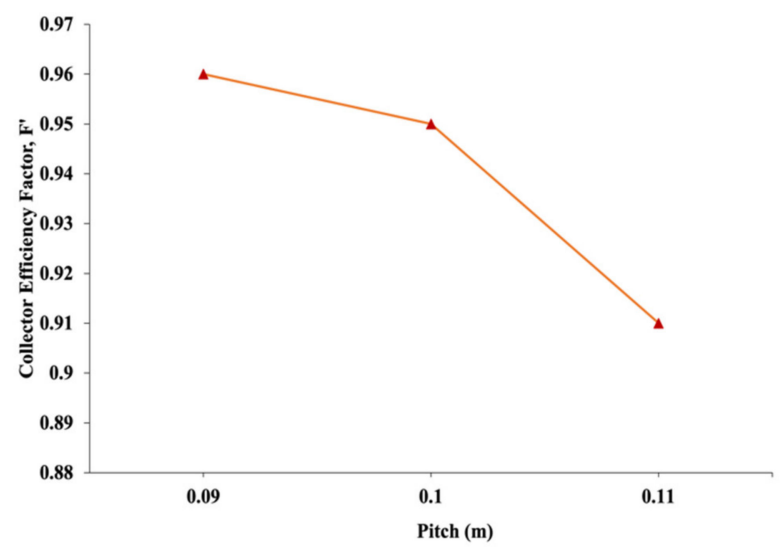

(a)

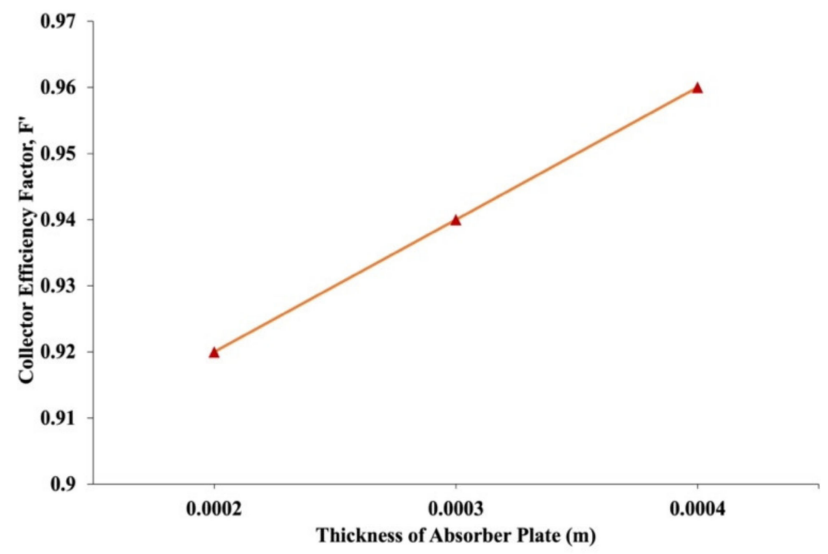

(b)

Figure 6. Collector efficiency factor variations due to different factors: (a) pitch of tubes; (b) absorber plate thickness.

The effect of the efficiency of the collector $(\eta)$ on the $F^{\prime}$ (Figure 7) resembled the prominence of the collector tube arrangement, i.e., when placed below the absorber plate, $\eta$ values ranged from $46 \%$ to $58 \%$, with variations in $\mathrm{F}^{\prime}$ ranging between 0.75 and 0.83 , while $\eta$ values ranged from $60 \%$ to $75 \%$ when the tubes were placed above the absorber plate, with varying $\mathrm{F}^{\prime}$ values ranging from 0.91 to 0.95 . 


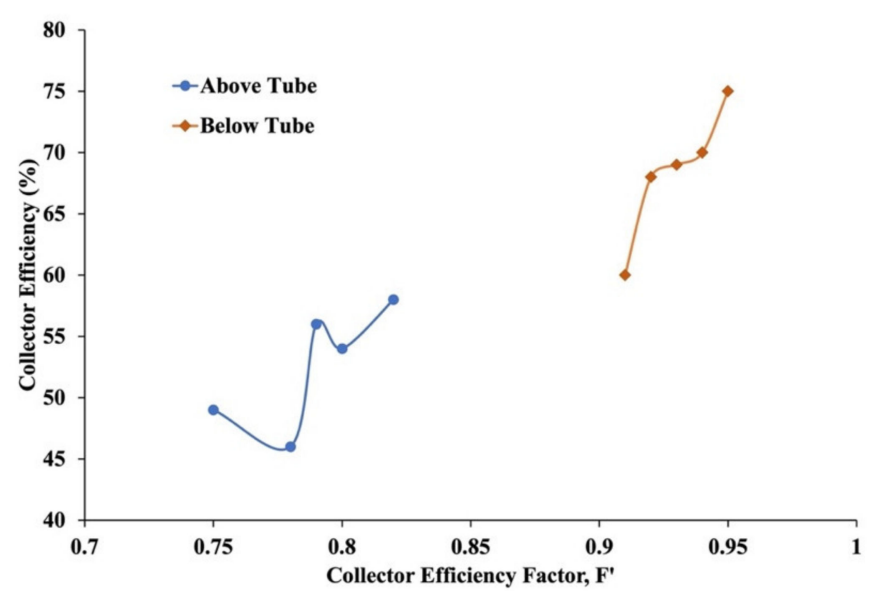

Figure 7. Collector efficiency factor variations.

Figure 8a depicts the increases in evaporator temperature with increasing solar radiation. Increases in evaporator temperature also increased the performance of the SAHPSWH.

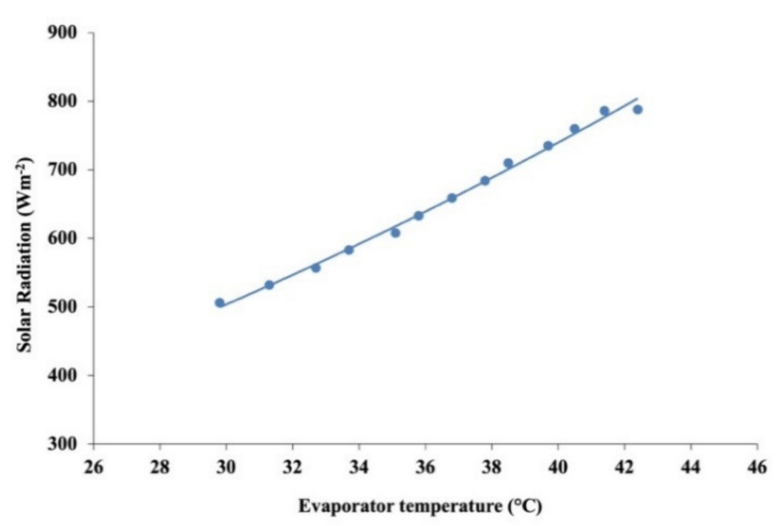

(a)

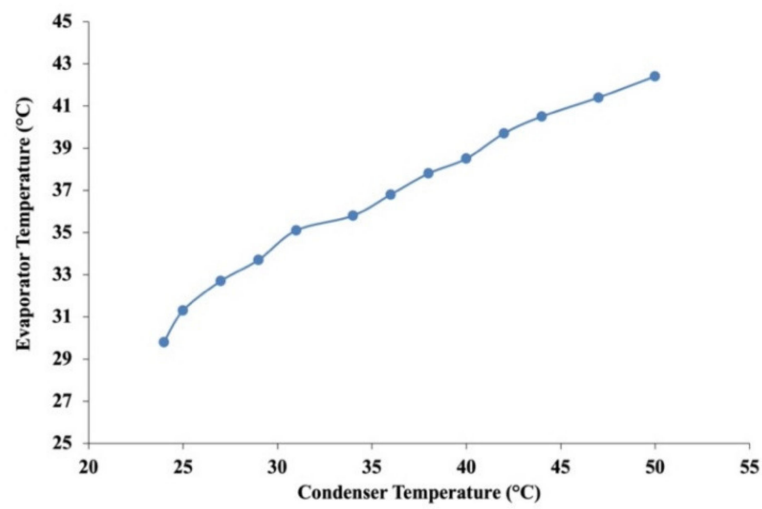

(b)

Figure 8. Effects of various factors on evaporator temperature: (a) solar radiation; (b) condenser temperature.

Figure $8 \mathrm{~b}$ shows the effects of the evaporator temperature on the condenser temperature, showing that with the increases in evaporator temperature, the working fluid condensing temperature also increased. Nevertheless, the effects of the solar radiation on the evaporator temperature were greater than that of the condenser temperature. When solar radiation started decreasing, the evaporator temperature decreased irrespective of the condensing temperature, showing that at a higher temperature, evaporation takes place in the system, which in turn improves the performance of the system.

The evaporator temperature is not allowed to exceed a certain value, as the compressor may get damaged when pushed beyond its operating limits. In the case of the below tube arrangement, the evaporation temperature may have been equal to ambient temperature; hence, better performance for the SAHPSWH was achieved as compared to the above tube arrangement shown in Figure 9.

An increase in $\mathrm{COP}$ with the increasing evaporation temperature due to its higher heat transfer rate than condenser can be observed in Figure 10. The relations between the collector efficiency factor $\left(\mathrm{F}^{\prime}\right)$ and collector efficiency $(\eta)$ for different sheet and tube arrangements are presented in Table 3, which shows that the efficiency of the below tube arrangement was better than the above tube evaporator arrangement. 


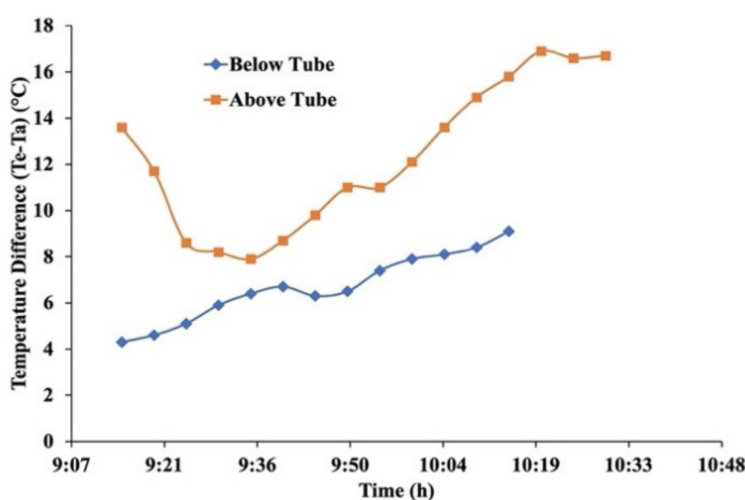

Figure 9. Variations in the temperature difference (Te-Ta) with time.

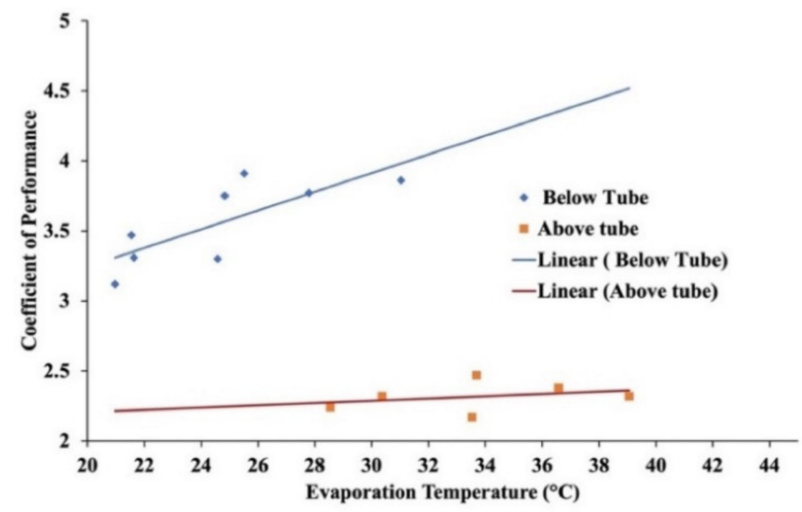

Figure 10. COP of the system with varying evaporator temperature.

Table 3. Collector efficiency factor and collector efficiency values when evaporator tubes were placed above and below the plate.

\begin{tabular}{cccccc}
\hline & (a) Above the Plate & & \multicolumn{3}{c}{ (b) Below the Plate } \\
\hline Test & $\mathbf{F}^{\prime}$ & $\mathbf{\eta} / \mathbf{1 0 0}$ & Test & $\mathbf{F}^{\prime}$ & $\boldsymbol{\eta} / \mathbf{1 0 0}$ \\
\hline Day 1 & 0.8 & 0.54 & Day 1 & 0.95 & 0.75 \\
\hline Day 2 & 0.82 & 0.58 & Day 2 & 0.95 & 0.72 \\
\hline Day 3 & 0.79 & 0.56 & Day 3 & 0.94 & 0.69 \\
\hline
\end{tabular}

\subsection{Effect of Different Glazing}

Experiments were performed with a single-glazed flat plate collector and a doubleglazed flat plate collector, as shown in Figure 11a,b.

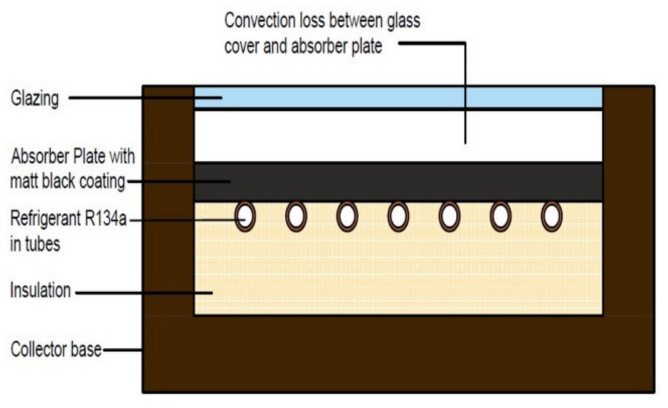

(a)

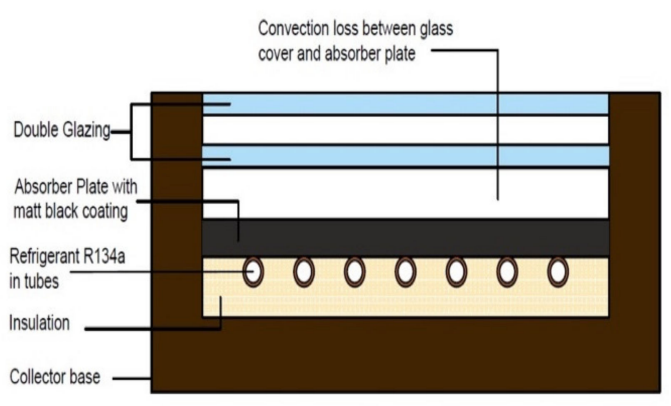

(b)

Figure 11. Different evaporator setups: (a) single-glazed evaporator; (b) double-glazed evaporator. 
Figure 12 presents the increases in storage tank temperature with increasing evaporation temperature. With a limited compressor capacity temperature, the evaporator is not allowed to exceed a certain limit. According to the performance characteristic analysis for the single-glazed evaporator, the evaporation temperature could not surpass $23.1^{\circ} \mathrm{C}$, which is near ambient temperature; however, for the double-glazed evaporator, it exceeded the ambient temperature of $36.7^{\circ} \mathrm{C}$, achieving better performance for the heat pump.

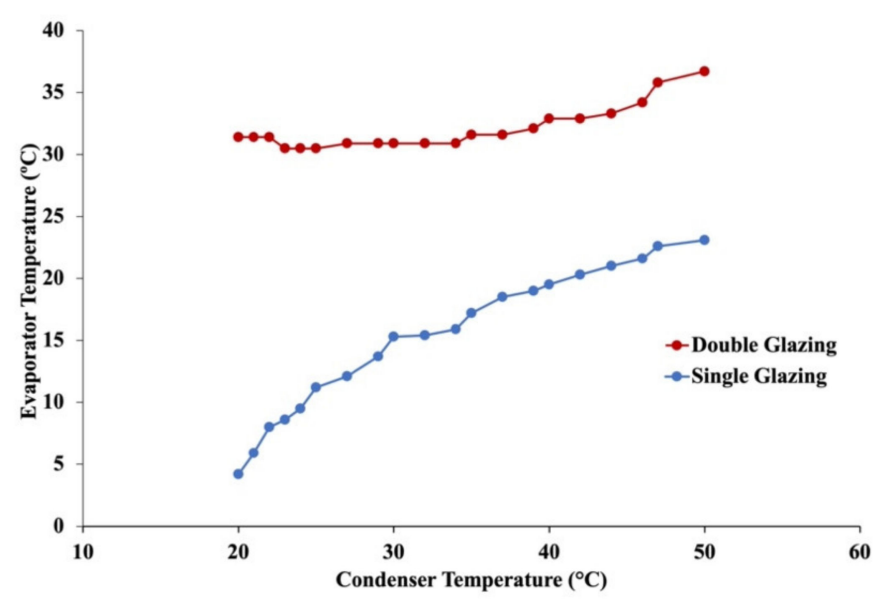

Figure 12. Evaporator temperature variations with storage tank temperature.

For single glazing, the evaporation temperature range was $5.9-22.6{ }^{\circ} \mathrm{C}$ and the maximum heat gain was $0.0696 \mathrm{kWh}$, while for double glazing, the evaporation temperature range was $30.5-36.7^{\circ} \mathrm{C}$ and the maximum heat gain was $0.104 \mathrm{kWh}$. If we compare both cases, due to high evaporation temperature, greater heat gain was found with double glazing. Therefore, double glazing results in better performance than single glazing. This also shows that the heat pump with the double-glazed evaporator produced higher evaporation temperatures and greater heat gain at the condenser than the single-glazed evaporator, resulting in better performance.

Figure 13 shows the effects of the evaporation temperature on COP. With an increase in solar radiation, the evaporation temperature also increases. The condensation rate, i.e., $Q_{w}$, increases with higher evaporation temperatures and the difference between the inlet and outlet reservoir temperatures also decreases; thus, the heat pump COP increases with increasing evaporation temperatures. The maximum COP value for the heat pump in the case of a single-glazed evaporator was 5.2, while in the case of the double-glazed evaporator, the maximum COP values reached 6.96; hence, it has been shown in the figures that the SAHPSWH with the double-glazed evaporator provides better COP values than the single-glazed evaporator.

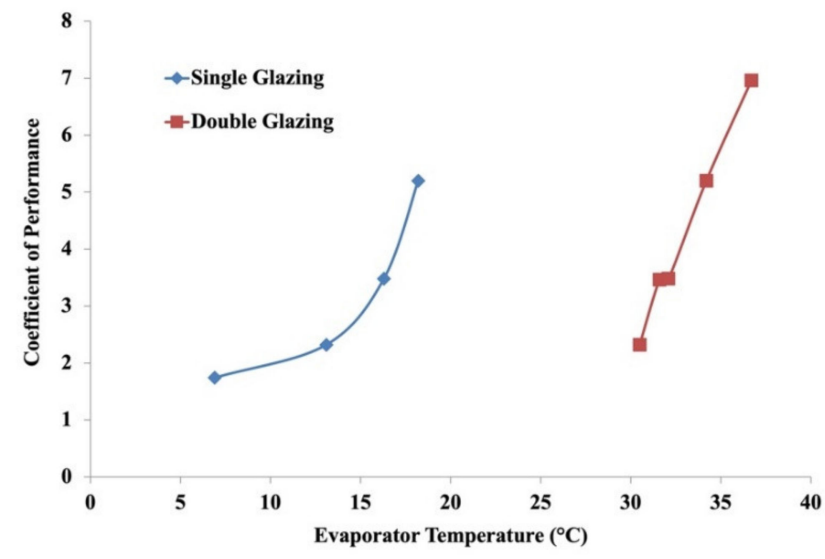

Figure 13. Effects of evaporation temperature on COP. 
Figure 14a shows the variations of the water tank temperature with solar radiation during the period of the experiments. As the radiation values increase, the evaporator temperatures also increase, meaning the heat transfer rate at the condenser also increases, due to which the water tank temperature increases. Figure $14 \mathrm{~b}$ shows the evaporation temperature variation with solar radiation during the period of the experiments. It was already mentioned that as the radiation values increase, the evaporation temperatures also increase.

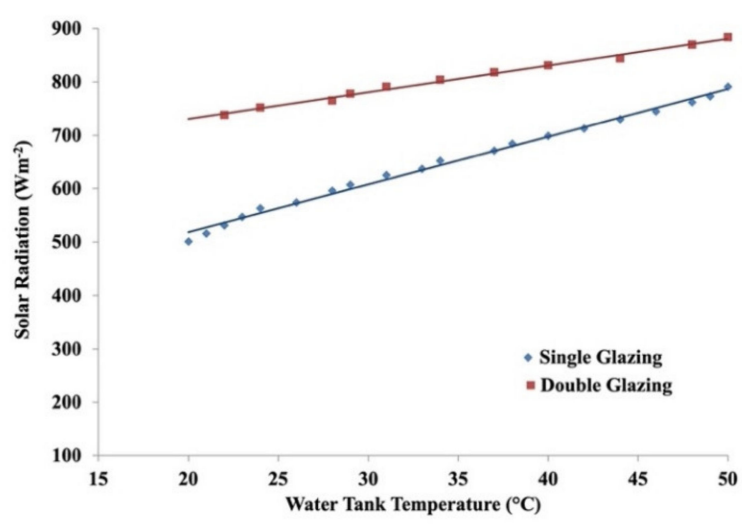

(a)

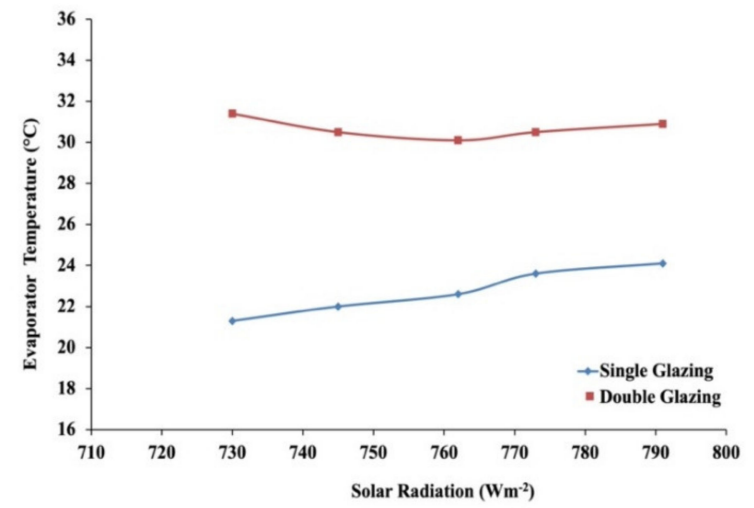

(b)

Figure 14. Temperature variations due to solar radiation: (a) water tank temperature; (b) evaporator temperature.

It can be observed from Figure 15 that the performance of the collector can be approximated by measuring the solar intensity $\left(\mathrm{I}_{\mathrm{T}}\right)$, fluid inlet temperature $\left(\mathrm{T}_{\mathrm{in}}\right)$, and ambient air temperature $\left(T_{a}\right)$, as the efficiency of the system becomes a linear function if $F_{R}, \tau, \alpha$, and $\mathrm{U}_{\mathrm{L}}$ are assumed to be constant for a particular flow rate and collector. Figure 16 shows that the collector efficiency highly depends on the collector's heat removal factor. The slope of the line $\left(-\mathrm{F}_{\mathrm{R}} \mathrm{U}_{\mathrm{L}}\right)$ in Figure 17 represents the rate of heat loss, which is lower in this case as compared to the single glazing arrangement.

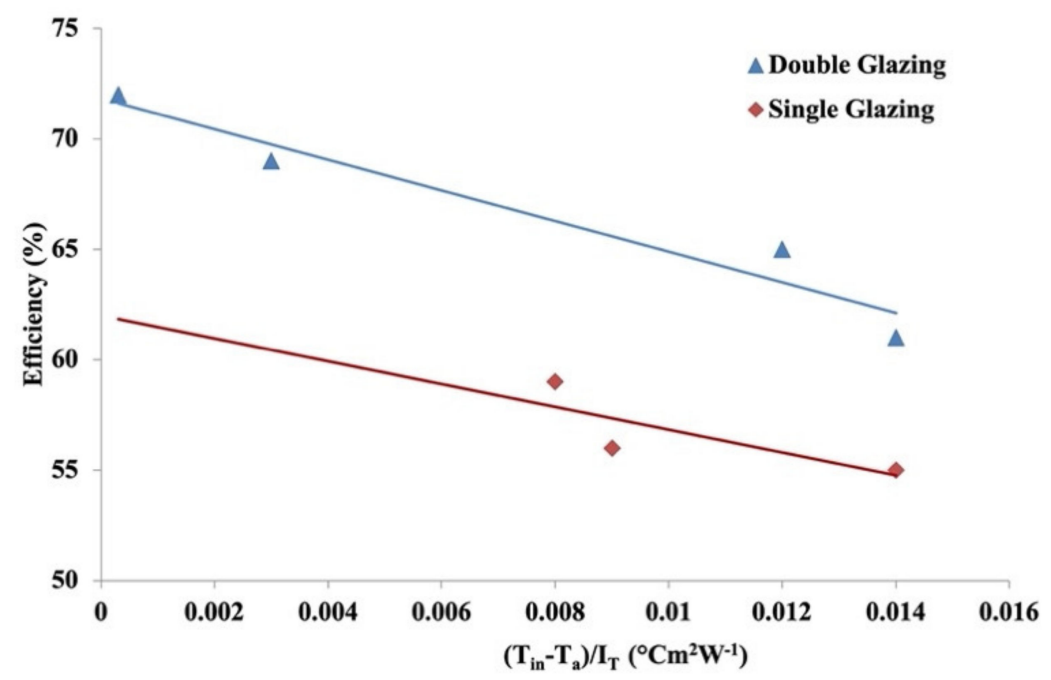

Figure 15. Performance of a typical flat-plate solar collector.

Figure 17 shows that the overall heat loss coefficient has a linear relationship with solar intensity, but for double glazing the overall heat loss coefficient is comparatively lower than for single glazing because the top heat loss coefficient is reduced as the number of glazing layers increases. Figure 18 shows the variation of solar radiation with time during the period of the experiments. There is no difference between the solar radiation in both cases. 
Table 4 shows the overall results of the experiments, depicting higher COP values when evaporator tubes are placed below the absorber plate with a double glazing arrangement.

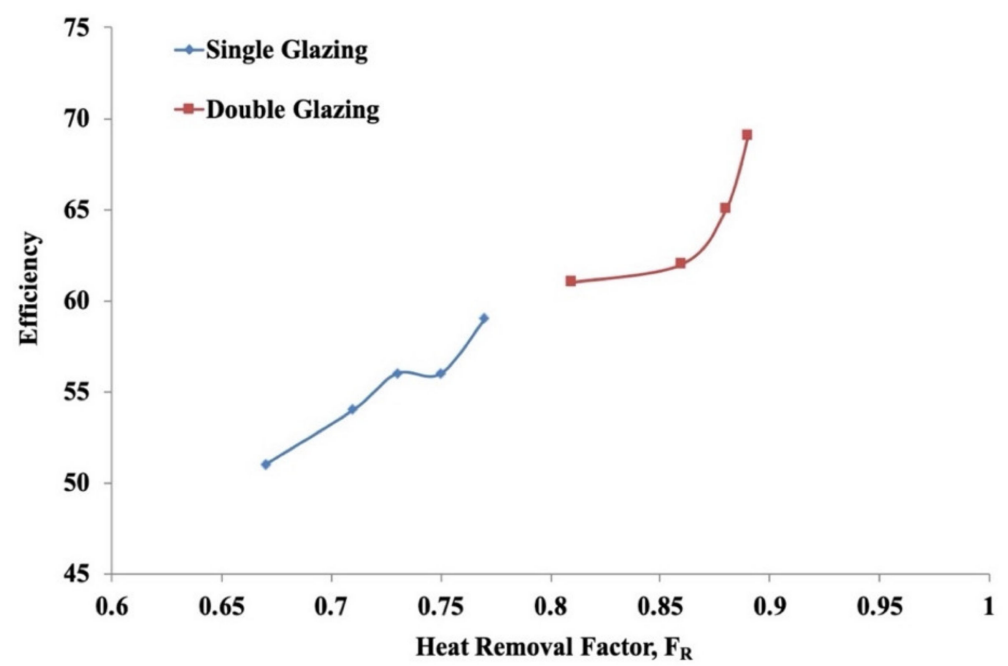

Figure 16. Heat removal factor variations due to the efficiency of the collector.

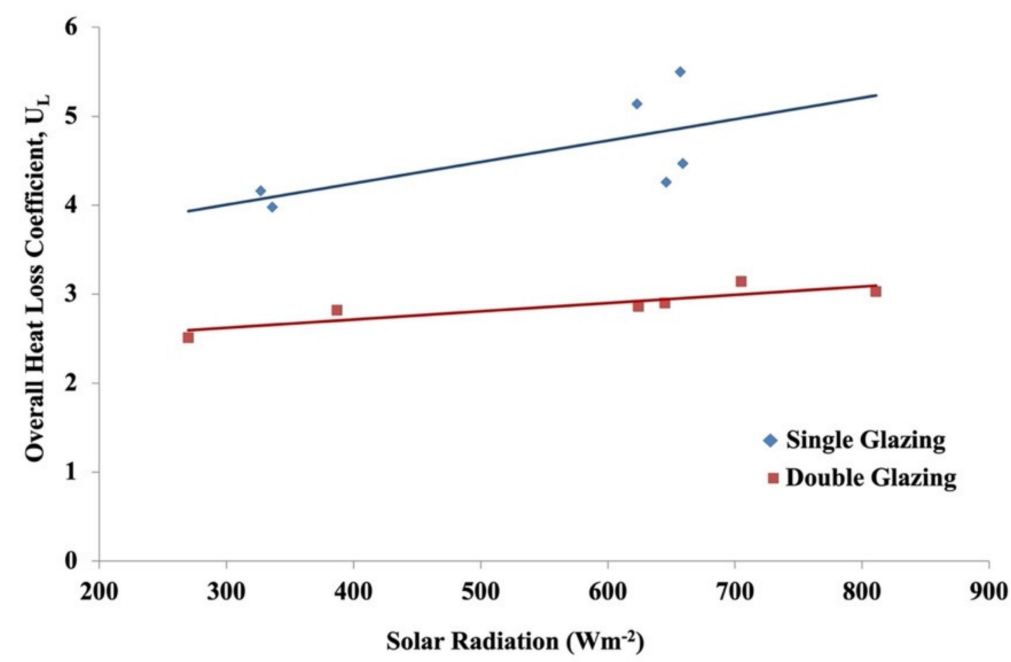

Figure 17. Variations of the overall heat loss coefficient with solar intensity.

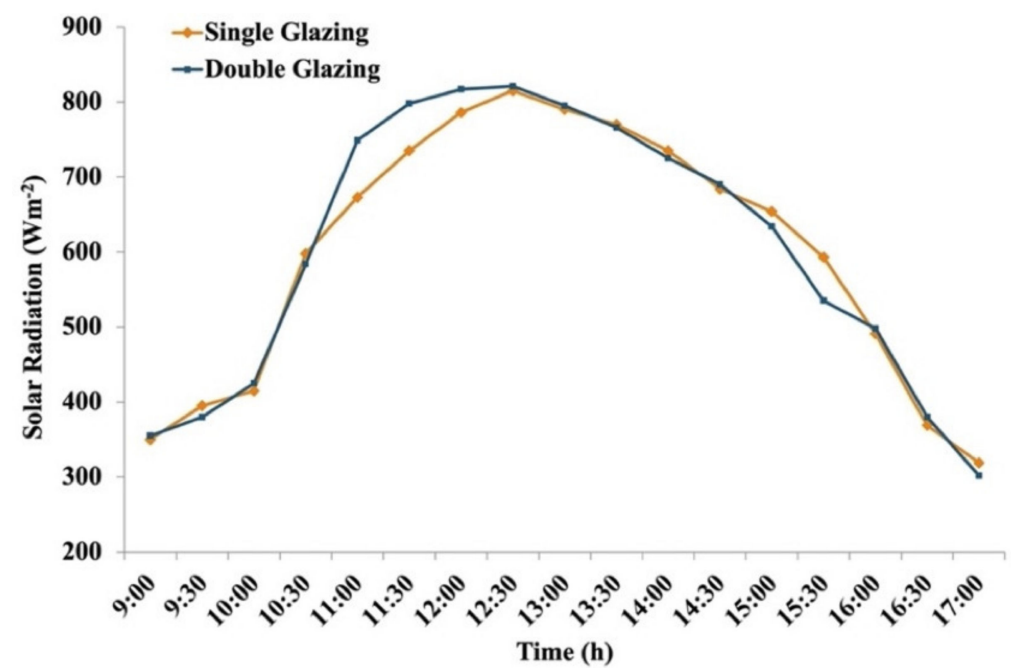

Figure 18. Solar radiation variation with time. 
Table 4. Key results of the experiment.

\begin{tabular}{ccccc}
\hline Different Configuration & Temperature Raised & Energy Consumption (KWh) & Time (min) & COP \\
\hline Tube above absorber plate & $27^{\circ} \mathrm{C}$ & $0.30-0.39$ & $55-75$ & $2.17-2.47$ \\
\hline Tube below absorber plate & $27^{\circ} \mathrm{C}$ & $0.18-0.29$ & $55-85$ & $3.12-3.91$ \\
\hline Single glazing & $30^{\circ} \mathrm{C}$ & $0.35-0.43$ & $95-110$ & $2.26-2.98$ \\
\hline Double glazing & $30^{\circ} \mathrm{C}$ & $0.25-0.34$ & $55-90$ & $2.86-3.89$. \\
\hline
\end{tabular}

\section{Conclusions}

This study was undertaken to examine the performance of the SAHPSWH and to find the best sheet and tube arrangement for flat plate collectors in colder climates of India. The experiment was performed in a composite climate during winter months. The tilt angle of the solar collector was $50^{\circ}$ during the experiment. The key conclusions are listed as follows:

- The results showed that $30 \mathrm{~L}$ of water could be heated from $23{ }^{\circ} \mathrm{C}$ to $50{ }^{\circ} \mathrm{C}$ in 55 to $75 \mathrm{~min}$ when evaporator tubes were soldered above the absorber plate, with energy consumption rates of about 0.30 to $0.39 \mathrm{kWh}$ and with COP values varying between 2.17 and 2.47;

- When evaporator tubes were soldered below the absorber plate, water was heated from $23{ }^{\circ} \mathrm{C}$ to $50{ }^{\circ} \mathrm{C}$ in 55 to $85 \mathrm{~min}$, while the energy consumption ranged from 0.18 to $0.29 \mathrm{kWh}$ and the COP values of the system ranged from 3.12 to 3.91 ;

- It is evident that for both cases, the heat gain was almost same, while the maximum COP was achieved in the second case. This result clearly shows that the performance of the system with the below tube arrangement was better than the above tube arrangement;

- The flat plate collector efficiency ranged from $46 \%$ to $58 \%$ when the tubes were placed below the absorber plate, with $\mathrm{F}^{\prime}$ values ranging between 0.75 to 0.83 . The efficiency ranged between $60 \%$ and $75 \%$ when the tubes were placed above the absorber plate, with $\mathrm{F}^{\prime}$ values ranging from 0.91 to 0.95 ;

- The efficiency factor of the collector $\left(\mathrm{F}^{\prime}\right)$ directly affects the efficiency of the solar flat plate collector $(\eta)$, which is influenced by two parameters, namely the center-to-center distance of the absorber tubes $\mathrm{W}$ and the absorber plate thickness $\delta$. The tube distance $\mathrm{W}$ had a strong influence on $\mathrm{F}^{\prime}$, which resulted in a decrease in $\mathrm{F}^{\prime}$ with an increase in $\mathrm{W}$. Consequently, by increasing the thickness of the absorber plate, a significant increase in $\mathrm{F}^{\prime}$ was observed;

- For different glazing arrangements, the results showed that in the SAHPSWH, $30 \mathrm{~L}$ of water could be heated from 20 to $50{ }^{\circ} \mathrm{C}$ in $95-110 \mathrm{~min}$ with single glazing and with energy consumption of about 0.35 to $0.43 \mathrm{kWh}$ and with COP ranging from 2.26 to 2.98. In the second case, the SAHPSWH with the double-glazed flat plate collector heated $30 \mathrm{~L}$ of water in the morning session from 20 to $50{ }^{\circ} \mathrm{C}$ in about $55-90 \mathrm{~min}$, with energy consumption of about 0.25 to $0.34 \mathrm{kWh}$ and with COP values ranging from 2.86 to 3.89 . For both cases, the energy gain was almost same. This result clearly shows that the system performance with the double-glazed flat plate collector was better than with the single-glazed flat plate collector in the SAHPSWH;

- The collector efficiency is strongly influenced by the parameter (Ti-Ta) $/ \mathrm{I}_{\mathrm{T}}$; if this parameter increases then collector efficiency decreases, because the slope of this line $\left(F_{R} U_{L}\right)$ represents the rate of heat loss from the collector. This slope decreased as the number of glazing layers increased from zero to three.

The SAHPSWH model in this study showed the best energy savings and has applicability for variable weather conditions. This is especially important for regions with a composite climate such as India, where space conditioning and water heating are required year-round. The present study has verified that the SAHPSWH is very reliable if it is carefully designed. 
Author Contributions: Conceptualization, C.S.M.; methodology, C.S.M.; validation, C.S.M.; formal analysis, B.P.R., L.S., and N.A.; investigation, C.S.M., B.P.R., L.S., and N.A.; resources, C.S.M.; data curation, B.P.R., L.S., and N.A.; writing-original draft preparation, C.S.M.; writing-review and editing, C.S.M., B.P.R., L.S., N.A. and A.G.; visualization, B.P.R. and C.S.M.; supervision, C.S.M.; funding acquisition, C.S.M. and A.G. All authors have read and agreed to the published version of the manuscript.

Funding: This research received no external funding.

Data Availability Statement: The data are not publicly available due to privacy considerations.

Acknowledgements: The paper is submitted for publication with the permission of the Director, CSIR-Central Building Research Institute, Roorkee.

Conflicts of Interest: The authors declare no conflict of interest.

\section{Nomenclature}

\begin{tabular}{|c|c|c|}
\hline Symbol & Nomenclature & Unit \\
\hline C & Specific heat capacity & $\mathrm{Jkg}^{-1} \mathrm{~K}^{-1}$ \\
\hline M & Number of covers & - \\
\hline $\mathrm{COP}$ & Coefficient of performance & - \\
\hline$A_{C}$ & Area of collector & $\mathrm{m}^{2}$ \\
\hline$h_{W}$ & Wind heat transfer coefficient & $\mathrm{Wm}^{-2} \mathrm{~K}^{-1}$ \\
\hline $\mathrm{I}_{\mathrm{T}}$ & Incident solar radiation on the collector & $\mathrm{Wm}^{-2}$ \\
\hline$K_{P}$ & Thermal conductivity of absorber plate & $\mathrm{Wm}^{-1} \mathrm{~K}^{-1}$ \\
\hline $\mathrm{Qu}_{\mathrm{u}}$ & Useful heat gain by collector & $\mathrm{W}$ \\
\hline $\mathrm{T}_{\mathrm{a}}$ & Ambient temperature & ${ }^{\circ} \mathrm{C}$ \\
\hline $\mathrm{T}_{\mathrm{P}}$ & The temperature of the absorber plate & ${ }^{\circ} \mathrm{C}$ \\
\hline $\mathrm{U}_{\mathrm{L}}$ & Overall heat loss coefficient & $\mathrm{Wm}^{-2} \mathrm{C}^{-1}$ \\
\hline $\mathrm{U}_{\mathrm{t}}$ & Top loss coefficient & $\mathrm{Wm}^{-1} \mathrm{~K}^{-1}$ \\
\hline $\mathrm{U}_{\mathrm{b}}$ & Bottom loss coefficient & $\mathrm{Wm}^{-1} \mathrm{~K}^{-1}$ \\
\hline $\mathrm{U}_{\mathrm{e}}$ & Edge loss coefficient & $\mathrm{Wm}^{-1} \mathrm{~K}^{-1}$ \\
\hline V & Wind velocity & $\mathrm{ms}^{-1}$ \\
\hline $\mathrm{F}^{\prime}$ & Collector efficiency factor & - \\
\hline $\mathrm{T}_{\mathrm{e}}$ & Evaporator temperature & ${ }^{\circ} \mathrm{C}$ \\
\hline$\varepsilon_{\mathrm{p}}$ & Emissivity of absorber plate & - \\
\hline$\varepsilon_{\mathrm{g}}$ & Emissivity of glass cover & - \\
\hline$\beta$ & Inclination angle of collector & $\circ$ \\
\hline W & Pitch of tubes & $\mathrm{m}$ \\
\hline b & Width of bond & $\mathrm{m}$ \\
\hline $\mathrm{D}_{\mathrm{O}}$ & Tube outside diameter & $\mathrm{m}$ \\
\hline $\mathrm{D}_{\mathrm{i}}$ & Tube inside diameter & $\mathrm{m}$ \\
\hline $\mathrm{h}_{\mathrm{fi}}$ & Inlet fluid heat transfer coefficient & $\mathrm{Wm}^{-2} \mathrm{~K}^{-1}$ \\
\hline $\mathrm{C}_{\text {bond }}$ & Bond conductance & $\mathrm{mKW}^{-1}$ \\
\hline $\mathrm{F}$ & Fin efficiency & - \\
\hline$\delta_{\mathrm{p}}$ & Thickness of absorber plate & $\mathrm{m}$ \\
\hline$\dot{\mathrm{m}}_{\mathrm{r}}$ & Mass flow rate of the refrigerant (R-134a) & $\mathrm{Kgs}^{-1}$ \\
\hline$\eta_{v}$ & Volumetric efficiency of the collector & - \\
\hline$P_{2}$ & Pressure at the outlet of compressor-inlet of condenser & $\mathrm{Kgs}^{-1}$ \\
\hline$P_{1}$ & Pressure at the inlet of compressor-exit of evaporator & $\mathrm{Kgs}^{-1}$ \\
\hline$\eta$ & Efficiency & - \\
\hline
\end{tabular}

\section{References}

1. Aggarwal, V.; Meena, C.S.; Kumar, A.; Alam, T.; Kumar, A.; Ghosh, A.; Ghosh, A. Potential and future prospects of geothermal energy in space conditioning of buildings: India and worldwide review. Sustainability 2020, 12, 8428. [CrossRef]

2. Agarwal, N.; Meena, C.S.; Raj, B.P.; Saini, L.; Kumar, A.; Gopalakrishnan, N.; Kumar, A.; Balam, N.B.; Alam, T.; Kapoor, N.R.; et al. Indoor Air Quality Improvement in COVID-19 Pandemic: Review. Sustain. Cities Soc. 2021, 70, 102942. [CrossRef] [PubMed]

3. Zeng, R.; Wang, X.; Di, H.; Jiang, F.; Zhang, Y. New concepts and approach for developing energy efficient buildings: Ideal specific heat for building internal thermal mass. Energy Build. 2011, 43, 1081-1090. [CrossRef] 
4. Bellos, E.; Tzivanidis, C.; Moschos, K.; Antonopoulos, K.A. Energetic and financial evaluation of solar assisted heat pump space heating systems. Energy Convers. Manag. 2016, 120, 306-319. [CrossRef]

5. Huang, Y.; Niu, J.; Chung, T. Study on performance of energy-efficient retrofitting measures on commercial building external walls in cooling-dominant cities. Appl. Energy 2013, 103, 97-108. [CrossRef]

6. Tzivanidis, C.; Bellos, E.; Mitsopoulos, G.; Antonopoulos, K.A.; Delis, A. Energetic and financial evaluation of a solar assisted heat pump heating system with other usual heating systems in Athens. Appl. Therm. Eng. 2016, 106, 87-97. [CrossRef]

7. Nozik, A.J. Photoelectrochemistry: Applications to Solar Energy Conversion. Ann. Rev. Phys. Chem. 2003, 29, 189-222. [CrossRef]

8. Lewis, N.S. Toward cost-effective solar energy use. Science 2007, 315, 798-801. [CrossRef]

9. Li, B. Integration of Solar Systems with Heat Pumps and Other Technologies. In Handbook of Energy Systems in Green Buildings; Wang, R., Zhai, X., Eds.; Springer: Berlin/Heidelberg, Germany, 2017; pp. 1372-1407.

10. Tagliafico, L.A.; Scarpa, F.; Valsuani, F. Direct Expansion Solar-Assisted Heat Pumps-A Clean Steady State Approach for Overall Performnace Analysis. Appl. Therm. Eng. 2014, 66, 216-226. [CrossRef]

11. Alam, T.; Meena, C.S.; Balam, N.B.; Kumar, A.; Cozzolino, R. Thermo-Hydraulic Performance Characteristics and Optimization of Protrusion Rib Roughness in Solar Air Heater. Energies 2021, 14, 3159. [CrossRef]

12. Fernández-seara, J.; Piñeiro, C.; Dopazo, J.A.; Fernandes, F.; Sousa, P.X.B. Experimental analysis of a direct expansion solar assisted heat pump with integral storage tank for domestic water heating under zero solar radiation conditions. Energy Convers. Manag. 2012, 59, 1-8. [CrossRef]

13. Li, Y.; Kao, W. Performance analysis and economic assessment of solar thermal and heat pump combisystems for subtropical and tropical region. Sol. Energy 2017, 153, 301-316. [CrossRef]

14. Nuntaphan, A.; Chansena, C.; Kiatsiriroat, T. Performance analysis of solar water heater combined with heat pump using refrigerant mixture. Appl. Energy 2009, 86, 748-756. [CrossRef]

15. Huan, C.; Li, S.; Wang, F.; Liu, L.; Zhao, Y.; Wang, Z.; Tao, P. Performance Analysis of a Combined Solar-Assisted Heat Pump Heating System in Xi'an, China. Energies 2019, 12, 2515. [CrossRef]

16. Kong, X.; Li, J.; Wang, B.; Li, Y. Numerical study of a direct-expansion solar-assisted heat pump water heater under frosting conditions based on experiments. Sol. Energy 2020, 196, 10-21. [CrossRef]

17. Cutic, T.; Pasanec, J.; Baleta, J.; Soldo, V.; Curko, T. Mobile Solar-Assisted Heat Pump with Direct Expansion. In Proceedings of the EuroSun 2012-ISES Europe Solar Conference, Rijeka, Croatia, 18-20 September 2012.

18. Bastos, H.M.C.; Torres, P.J.G.; Álvarez, C.E.C. Numerical simulation and experimental validation of a solar-assisted heat pump system for heating residential water. Int. J. Refrig. 2018, 86, 28-39. [CrossRef]

19. Buker, M.S.; Riffat, S.B. Solar assisted heat pump systems for low temperature water heating applications: A systematic review. Renew. Sustain. Energy Rev. 2016, 55, 399-413. [CrossRef]

20. Chaturvedi, S.K.; Abdel-Salam, T.M.; Sreedharan, S.S.; Gorozabel, F.B. Two-Stage Direct Expansion Solar-Assisted Heat Pump for High Temperature Applications. Appl. Therm. Eng. 2009, 29, 2093-2099. [CrossRef]

21. Morrison, G.L. Simulation of Packaged Solar Heat Pump Water Heaters. Sol. Energy 1994, 53, 149-257. [CrossRef]

22. Mehdaoui, F.; Hazami, M.; Naili, N.; Farhat, A. Energetic performances of an Optimized Passive Solar Heating Prototype used for Tunisian Buildings Air Heating Applications. Energy Convers. Manag. 2014, 87, 285-296. [CrossRef]

23. Bridgeman, A.G. Experimental Analysis of an Indirect Solar Assisted Heat Pump for DomesticWater Heating. Ph.D. Thesis, Queen's University, Kinsgton, ON, Canada, 2010.

24. DeGrove, J.M. The Integration of Heat Resources in a Solar Thermal Heat Pump Hydronic System. Ph.D. Thesis, Purdue University, West Lafayette, IN, USA, 2015.

25. Khalaf, K. Experimental Characterization and Modelling of a Heat Pump Water Heater. Ph.D. Thesis, Carleton University, Ottawa, ON, Canada, 2017.

26. Fu, Y. Investigation of Solar Assisted Heat Pump System Integrated with High Rise Residential Building. Ph.D. Thesis, University of Nottingham, Nottingham, UK, 2014.

27. Hu, Z.; Zhang, S.; Chu, W.; He, W.; Yu, C.; Yu, H. Numerical Analysis and Preliminary Experiment of a Solar Assisted Heat Pump Drying System for Chinese Wolfberry. Energies 2020, 13, 4306. [CrossRef]

28. Valancius, R.; Singh, R.M.; Jurelionis, A.; Vaiciunas, J. A Review of Heat Pump Systems and Applications in Cold Climates: Evidence from Lithuania. Energies 2019, 12, 4331. [CrossRef]

29. Zhao, Z.; Zhang, Y.; Mi, H.; Zhou, Y.; Zhang, Y. Experimental Research of a Water-Source Heat Pump Water Heater System. Energies 2018, 11, 1205. [CrossRef]

30. Mohanraj, M.; Belyayev, Y.; Jayaraj, S.; Kaltayev, A. Research and developments on solar assisted compression heat pump systems-A comprehensive review (Part A: Modeling and modifications). Renew. Sustain. Energy Rev. 2018, 83, 90-123. [CrossRef]

31. Thygesen, R. An Analysis of Different Solar-Assisted Heating Systems and Their Effect on the Energy Performance of Multifamily Buildings-A Swedish Case. Energies 2017, 10, 88. [CrossRef]

32. Klein, S.A. Calculation of Flat Plate Collector Loss Coefficients. Sol. Energy 1975, 17, 79-80. [CrossRef]

33. Duffie, J.A.; Beckman, W.A. Solar Engineering of Thermal Processes; John Wiley and Sons, Inc.: Hoboken, NJ, USA, $1991 ;$ pp. 164-165.

34. Duffie, J.A.; Beckman, W.A. Solar Engineering of Thermal Processes; John Wiley and Sons, Inc.: Hoboken, NJ, USA, 1991; pp. 148-149.

35. Chyng, J.P.; Lee, C.P.; Haung, B.J. Performance analysis of a solar-assisted heat pump water heater. Sol. Energy 2003, 74, 33-44. [CrossRef] 